$0.032 \mathrm{~mm}$; II, $0.032 \mathrm{~mm}$.; III, $0.128 \mathrm{~mm}$; IV (0.032 mm. +0.176 $\mathrm{mm}$.). Beak reaching to the hind coxæ, cornicles $0.048 \mathrm{~mm}$.

Second instar. Similar to the last in general color. Antennæ of five segments with the measurements as follows: Segment I, 0.048 mm.; II, $0.048 \mathrm{~mm}$; III, $0.112 \mathrm{~mm}$.; IV, $0.08 \mathrm{~mm}$.; V (0.048 $\mathrm{mm} .+0.224 \mathrm{~mm}$.). Cornicles $0.08 \mathrm{~mm}$. Beak reaching beyond the second coxæ. Hind tibia $0.272 \mathrm{~mm}$.

Third instar. General color similar to that of the previous instar, excepting that it is somewhat darker in color. Antennæ of five segments, with measurements as follows: Segment I, 0.064 mm.; II, $0.048 \mathrm{~mm}$.; III, $0.176 \mathrm{~mm}$.; IV, $0.112 \mathrm{~mm}$.; V (0.048 $\mathrm{mm} .+0.272 \mathrm{~mm}$.); cornicles $0.112 \mathrm{~mm}$. Hind tibia $0.368 \mathrm{~mm}$.

Fourth instar. General color similar to that of the last instar. Antennæ of six segments with measurements as follows: Segment III, 0.224 mm.; IV, $0.16 \mathrm{~mm}$.; V, $0.144 \mathrm{~mm}$.; VI $(0.08 \mathrm{~mm}$. + 0.368 $\mathrm{mm}$.). Segments imbricated but without secondary sensoria. Cornicles $0.192 \mathrm{~mm}$. long, tapering, but slightly swollen on the distal third and distinctly imbricated and flanged. Hind tibia 0.64 $\mathrm{mm}$. long; slightly swollen and thickly covered with nearly circular, tuberculate sensoria; length from vertex to tip of cauda $1.76 \mathrm{~mm}$. Type in U. S. National Museum.

\title{
A NEW SPECIES OF EVANIA FROM THE CAMEROONS (HYMENOPTERA; EVANIIDE).
}

\section{By Charles T. Brues, Bussey Institution, Harvard University.}

In working over a collection of Evaniidæ from South Africa, I have had occasion to examine a very interesting species from Western Africa. This was contained in a collection of Parasitic Hymenoptera given me by Prof. R. Thaxter, and the type has been deposited in the Museum of Comparative Zoölogy in Cambridge.

Evania flavocoxalis sp. nov.

Length $5 \mathrm{~mm}$. Black, the antennæ brown at the base; palpi, four anterior coxæ and trochanters, anterior side of anterior tibiæ and posterior coxæ below, except at apex, yellow. Wings hyaline with a brown tinge. Body very thinly pubescent, almost 
bare, except the hind tibiæ and tarsi which are more strongly pubescent than usual. Head rugosopunctate above the ocelli; front excavated gently above the antennæ, the basin finely longitudinally striate, space between it and the eyes more coarsely striate; between the antennæ is a strong carina that extends upward and disappears before the ocelli; beneath the antennæ is a transverse carina that curves upward outside them and extends halfway to the ocelli; face with deep striæ that converge below; cheeks with striæ that curve toward the base of the mandibles; head behind the eyes with scattered punctures of variable sizes, impunctate near the posterior edge and on the occiput except close to the ocelli. Cheeks half as long as the eyes, the inner edges of which are divergent below; ocelli close together in a low triangle, the

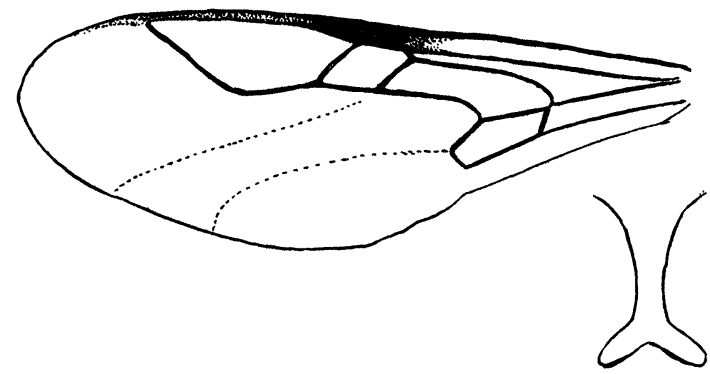

Fig. 1. Evania flavocoxalis sp. nov., fore wing and outline of metasternal process.

posterior ones larger than the anterior one, as far from one another as from the eye margin. Antennæ slender; third and fourth joints equal, each as long as the first two together and fully six times as long as thick. Mesonotum with distinct parapsidal furrows and with two other deep-grooved lines on each side external to the furrows; of these the inner one meets the furrow near its anterior end and the outer one meets the edge of the mesonotum just in front of the tegula; both attain the posterior margin of the mesonotum; surface of mesonotum irregularly punctate with coarse and fine punctures intermixed; smooth medially behind. Scutellum with large, well-separated punctures, smooth medially behind. Propodeum elongate, longer than the distance from its base to the anterior edge of the prothorax; not excavated behind, its posterior surface very gradually sloping, rounded off to the 
base of the coxæ; evenly reticulate, coarsely so behind the insertion of the abdomen, finely so at the base. Pleuræ punctatereticulate, the mesopleura with a long smooth space above that extends downward anteriorly. Metasternal process long and very narrow medially, its tines well-developed, widely divergent, and but slightly curved. Legs slender; hind coxæ microscopically transverse-reticulate; hind femora simple; hind leg not over twice as long as the body; longer spur of hind tibia half the length of the metatarsus. Petiole of abdomen coarsely obliquely striate except near the base. Wings with the basal vein lying closer than usual to the subcostal vein; cubitus arising very close to the junction of the basal and subcostal veins; nervulus interstitial with basal vein; radial vein meeting the subcosta at an acute angle; cubitus and subdiscoideus wanting beyond the cells. Hindwing with seven frenulum hooks.

This species is somewhat similar to $E$. verrucosipes Kieff. and might possibly be the male of that species which is known from the female only. However, the sculpture of the temples, scutellum, propodeum and petiole is entirely different and the thorax is nearly twice as long. From $E$. cristatifrons Kieff. also known from the female, it differs by the absence of the carina on the vertex and the pectinate process between the antennæ, by the sculpture of the petiole, and form of thorax. From $E$. divergens Kohl it is evidently distinct, although Kohl's description is very incomplete. The cheeks are shorter and the basal joints of the antennæ are much longer, and the color is different. The thorax is very much more elongate than in any other Evania that $I$ have seen and the antennæ are more slender. The thorax is fully twice as long as high and the propodeum slopes gradually from base to tip, whereas it usually bends abruptly with an almost vertical posterior face. 

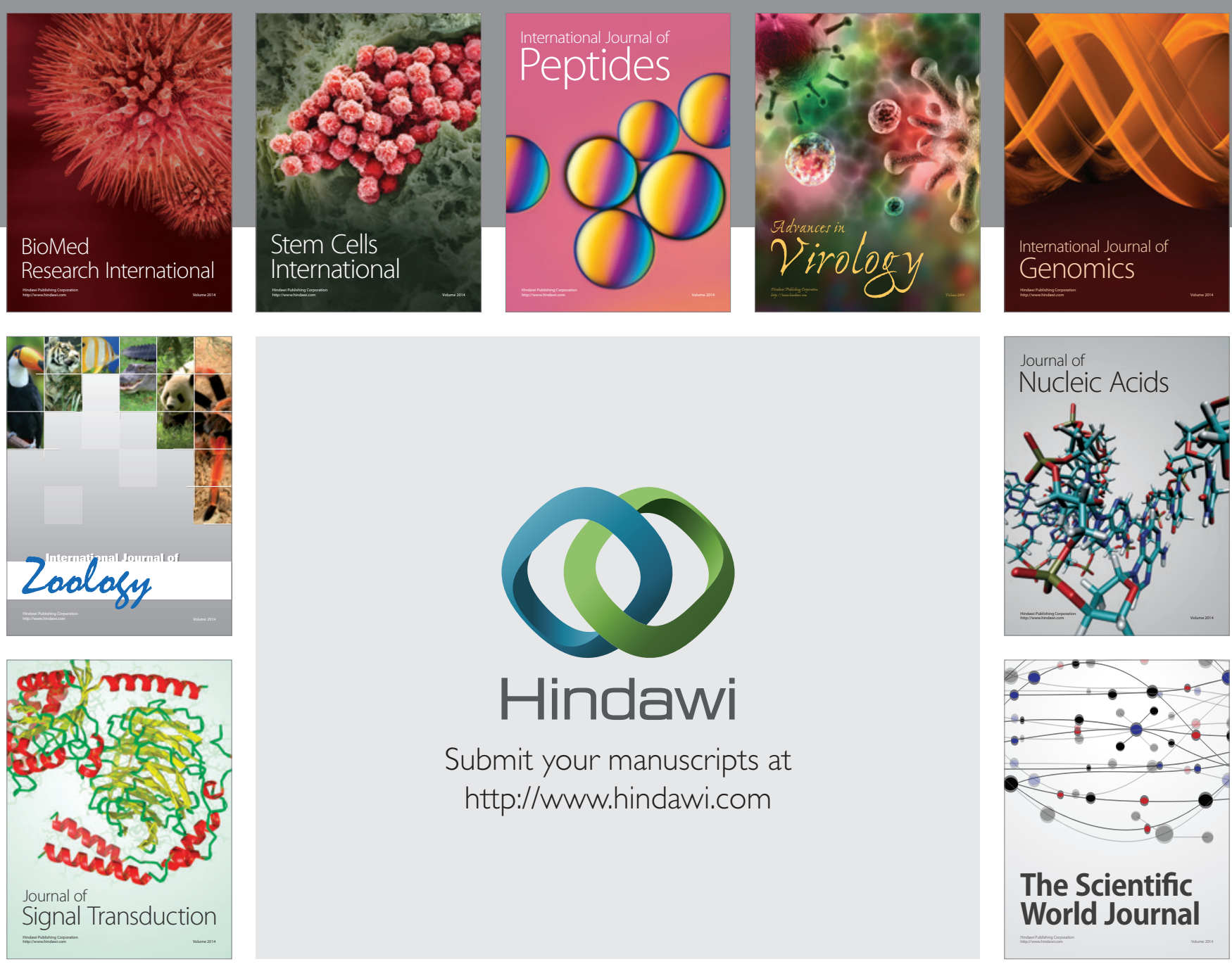

Submit your manuscripts at

http://www.hindawi.com
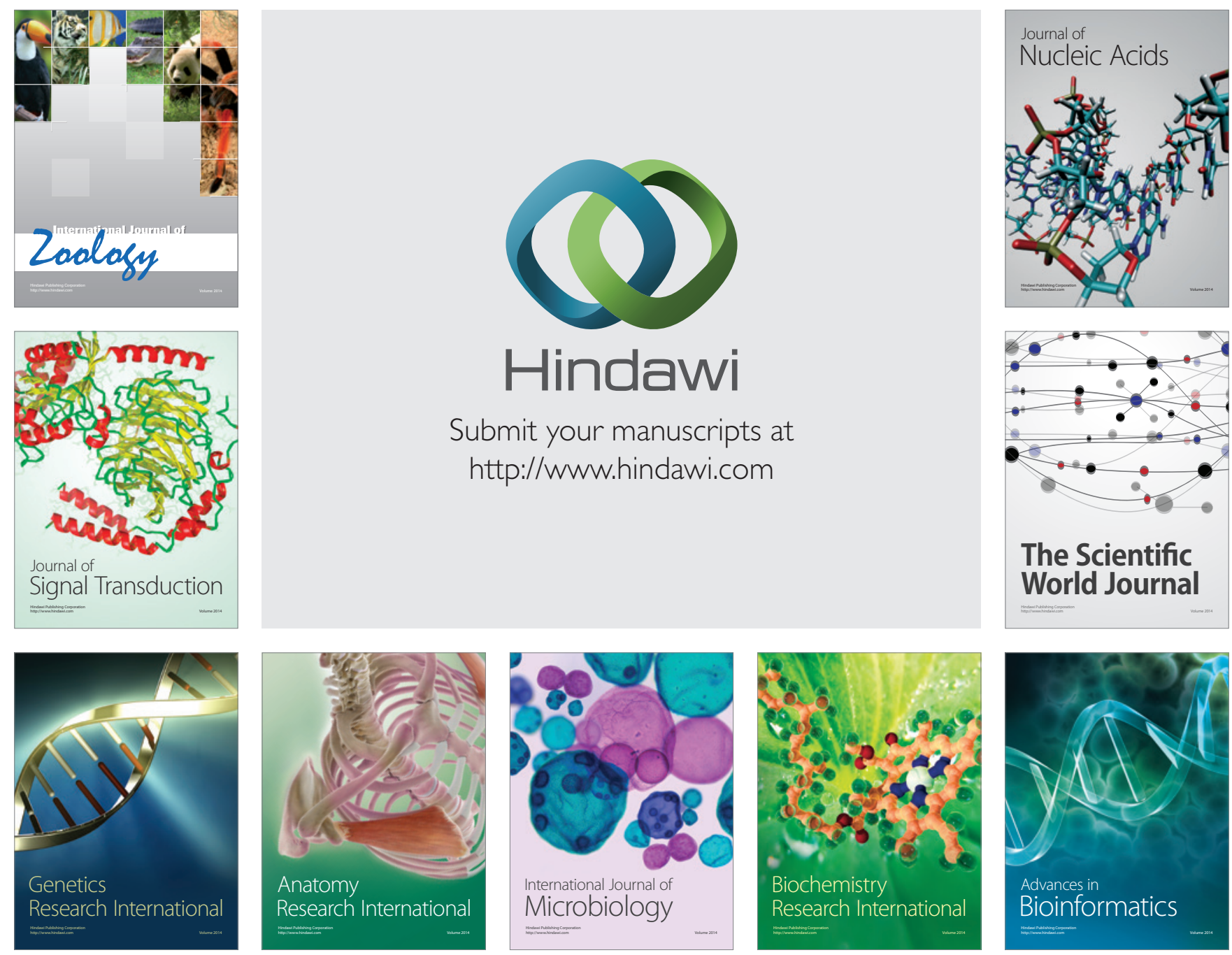

The Scientific World Journal
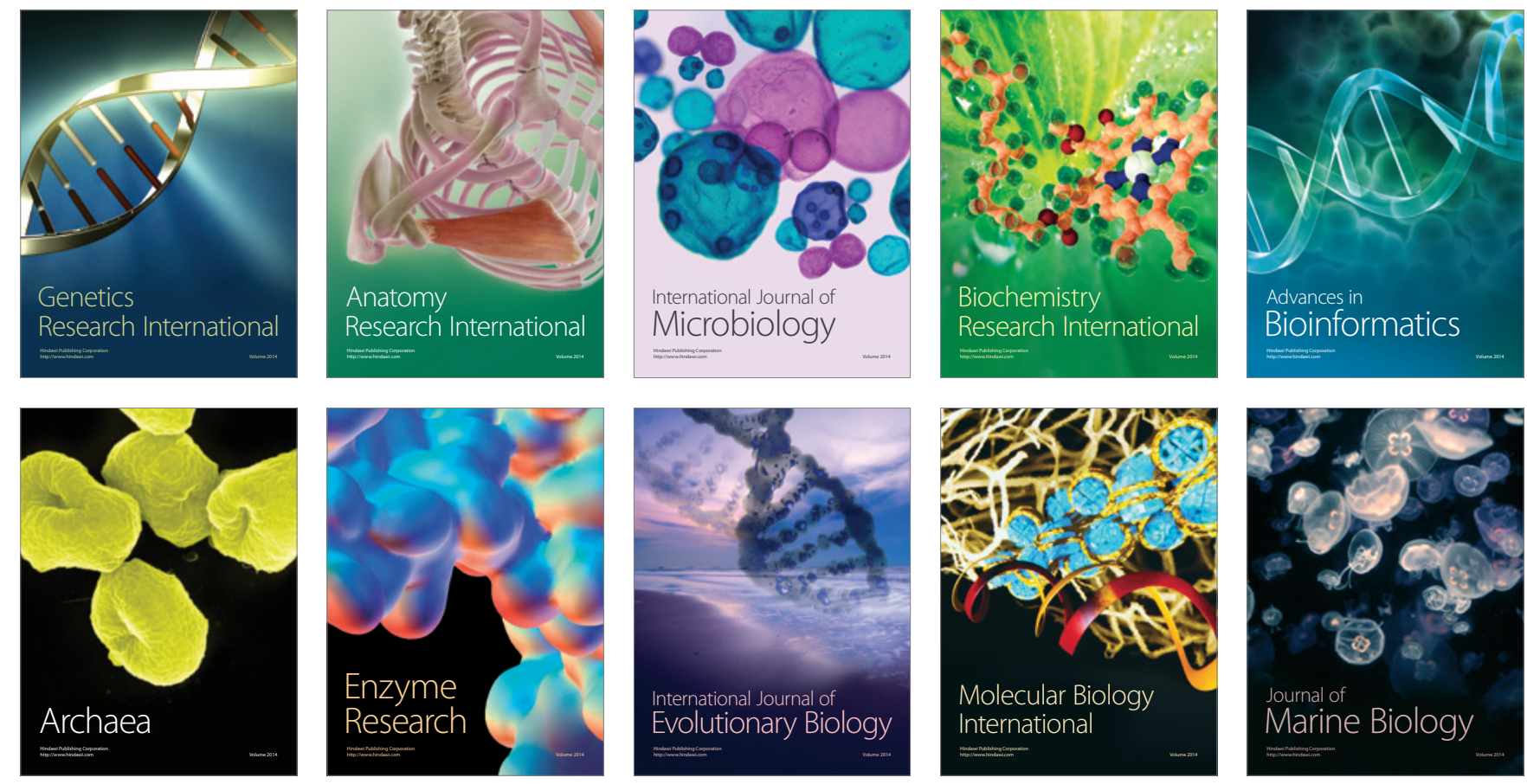